\title{
The flux, energy and heating calculations for reactor core designed with Monte Carlo modelling
}

\author{
Mehtap Düz ${ }^{1}$ and Selcan Inal ${ }^{2}$ \\ 1 İnönü University, Faculty of Arts and Sciences, Department of Physics, Malatya, Turkey \\ 2 İnönü University, Institute of Science, Malatya, Turkey.
}

Received: 13 June 2021, Accepted: 16 June 2021

Published online: 8 July 2021.

\begin{abstract}
In this study, a boiling water reactor (BWR) core modeling was performed using the Monte Carlo mathematical modelling (MCNPX-2.7.0 code and ENDF/B-VII library). In the modeling, an 8x8 square lattice was designed for the reactor core. In the designed square lattice; $0.65-0.7-0.75 \% \mathrm{NpO}_{2}$ and $\mathrm{NpF}_{4}$ were used as fuel rod, $\mathrm{Zr}-2$ and $\mathrm{SiC}$ for fuel cladding, water as coolant and $\mathrm{B}_{4} \mathrm{C}$ as control rod. In this study, neutron flux, fission energy and heating neutronic values were calculated for the selected fuel and clad in the designed BWR.
\end{abstract}

Keywords: MCNPX-2.7.0, flux, heating.

\section{Introduction}

Today, all of the energy obtained with reactors is provided by fission reactors. However, nuclear waste dropped from reactors while generating energy has become a major problem. Hiding of nuclear wastes in geological storage areas has been a way to date. However, considering the amount of waste left in tons of waste from existing reactors every year, it is thought that the idea of storing waste in storage areas is not a good solution. For this reason, theoretical studies on the reuse of wastes in order to reduce the amount of waste have gained momentum in recent years.

Nuclear waste from a reactor; uranium, plutonium, minor actinides (Np, Am, Cm) and fission products. Since minor actinides among these wastes have high power and radioxide effect, if they are used as fuel in the reactor, both energy production will be provided and the amount of waste will be reduced [1,2]. For this reason, in this study, a BWR was designed and $\mathrm{Np}$ mixed fuel $\left(\mathrm{NpO}_{2}\right.$ and $\left.\mathrm{NpF}_{4}\right)$ was used in the fuel rods of the design to reduce the amount of minor actinide and to generate energy.

\section{Materials and Methods}

The reactor core designed in this study; it is cylindrical with a radius of $264.08 \mathrm{~cm}$ and a height of $365.76 \mathrm{~cm}$. In the study, $5 \mathrm{~cm}$ thick SS316LN ferritic steel was used as a reflector and $\mathrm{B}_{4} \mathrm{C}$ as a control rod. Figure 1 shows the square lattice in the designed BWR. The reactor core was placed in an 8x8 square lattice, each $30.48 \mathrm{~cm}$ wide, and a 7x7 small square lattice, each $1.94084 \mathrm{~cm}$ wide, in each square latice.

Figure 2 shows the cell geometry in the small square lattice. In Figure 2, 0.65-0.75\% $\mathrm{NpO}_{2}$ and $\mathrm{NpF}_{4}$ fuel rod radius is $0.60579 \mathrm{~cm}$, gap width is $0.01524 \mathrm{~cm}, \mathrm{Zr}-2$ and $\mathrm{SiC}$ clad radius is $0.71501 \mathrm{~cm}$. 


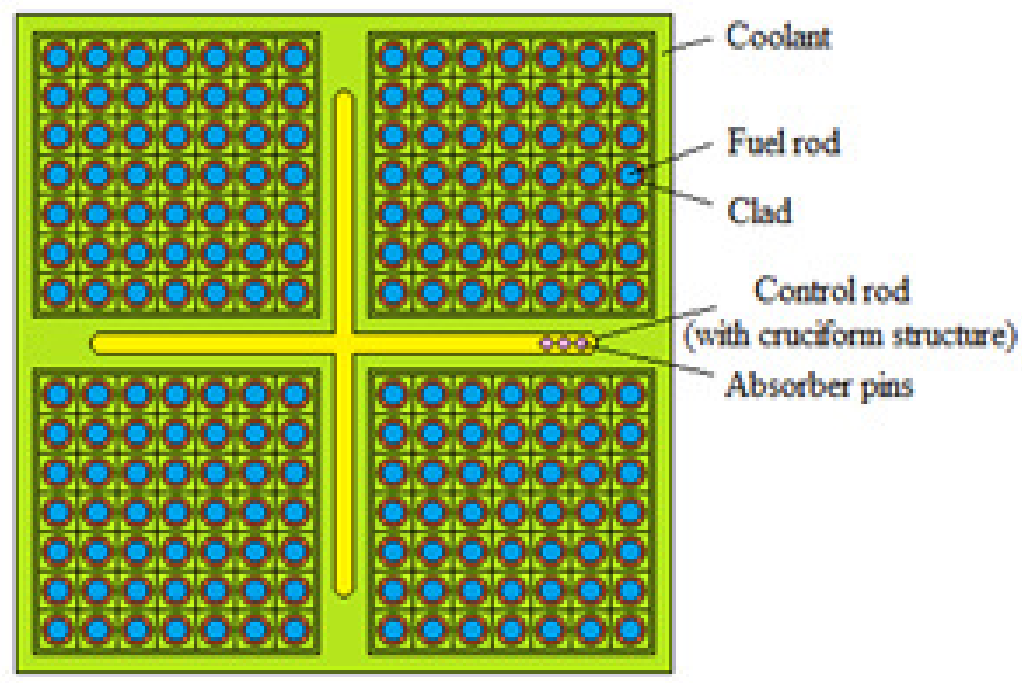

Fig. 1: Square lattice at the designed BWR.

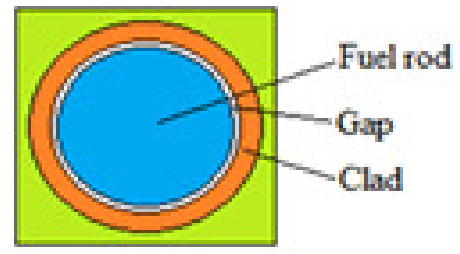

Fig. 2: Cell geometry.

In this study, Monte Carlo method was used for 3D BWR design. Monte Carlo method is a method of simulating an event numerically. MCNP is a general code that solves the time-dependent continuous energy transport (transport) of neutrons, photons and electrons in three-dimensional geometry. MCNP is a code that includes Monte Carlo simulation and a number of models, including physics and mathematics subjects with nuclear properties. MCNP code can be applied quite well in modeling complex particle migration, it uses continuous cross section data. When the codes that are successful in low energy radiation transport with the MCNP code in nuclear engineering and the codes that are successful in high energy radiation transport with the LAHET (Los Alamos High Energy Transport) code, the particles are transported at almost all energies. In the improved system, MCNP and LAHET codes were combined and MCNPX got its new code name. With its developed MCNPX code, it enables the calculation of radiation transport in high energy application areas in nuclear engineering [3-5]. In this study was used the code MCNPX-2.7.0, which is the latest version of MCNPX.

\section{Results}

In this study, neutron flux, fission energy and heating values were calculated for $0.65-0.7-0.75 \% \mathrm{NpO}_{2}$ and $\mathrm{NpF}_{4}$ fuels, Zr-2 and SiC cladding materials.

Figure 3-5 shows neutron flux, fission energy, heating, for $\mathrm{NpO}_{2}$ and $\mathrm{NpF}_{4}$ fuels and $\mathrm{Zr}-2$ and $\mathrm{SiC}$ cladding materials. As can be seen from Figure 3-5, neutron flux, fission energy, heating increase in both $\mathrm{Zr}-2$ and SiC cladding materials, as 
fuel ratios increase. The highest neutron flux, fission energy and heating were obtained from $0.75 \% \mathrm{NpO}_{2}$ fuel and $\mathrm{SiC}$ clad, and the lowest neutron flux, fission energy and heating from $0.65 \% \mathrm{NpF}_{4}$ fuel and $\mathrm{Zr}-2$ clad.

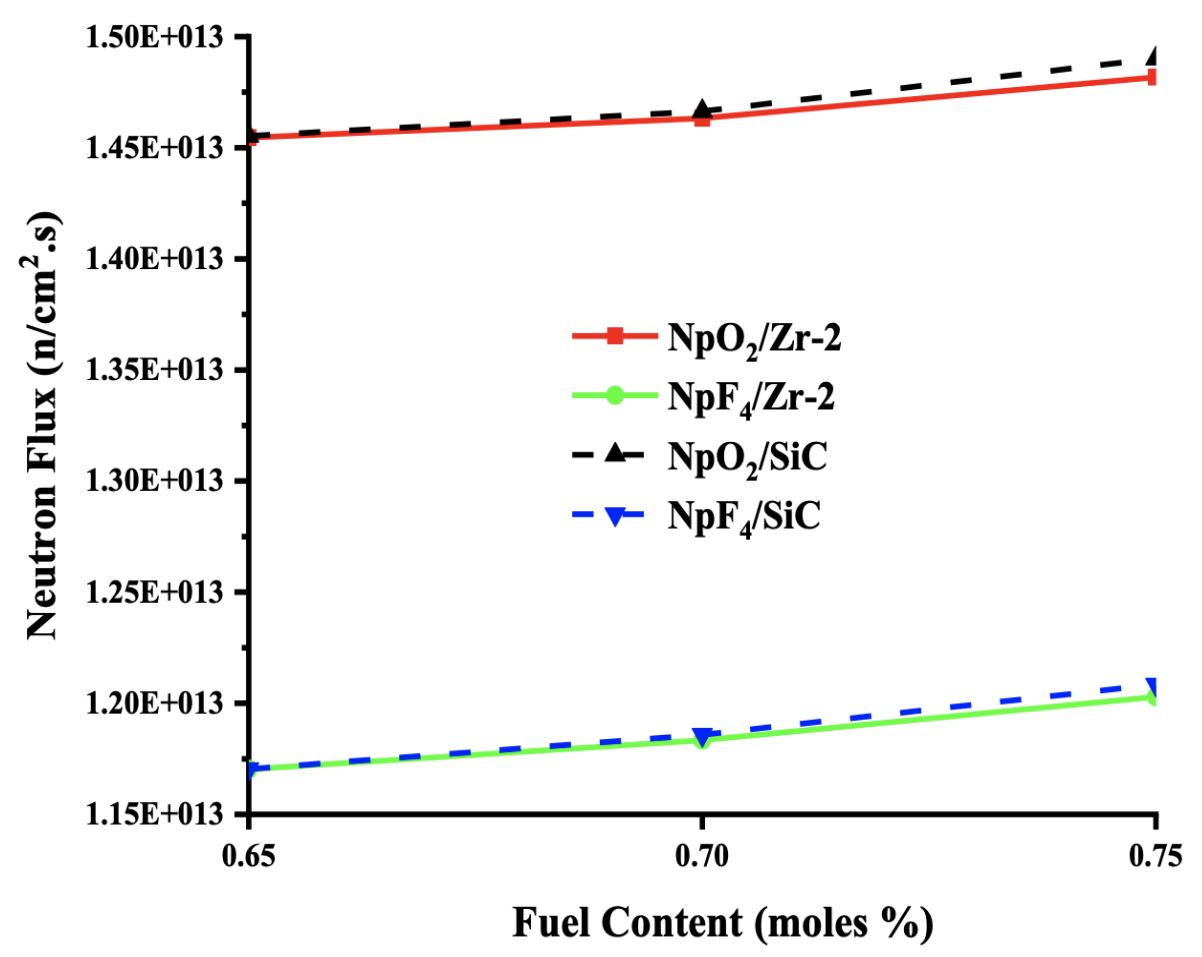

Fig. 3: The neutron flux for $\mathrm{Zr}-2$ and $\mathrm{SiC}$ clads, the fuel components $\mathrm{NpO}_{2}$ and $\mathrm{NpF}_{4}$.

\section{Conclusion}

In this study, three-dimensional BWR design was made using MCNPX-2.7.0 Monte Carlo code and ENDF/B-VII library. Neutron flux, fission energy and heating neutronic values were calculated using $0.65-0.7-0.75 \% \mathrm{NpO}_{2}$ and $\mathrm{NpF}_{4}$ fuels as fuel and $\mathrm{Zr}-2$ and $\mathrm{SiC}$ clads as cladding material in the reactor core design.

Since SiC's thermal neutron cross section (0.12 barn) is less than $\mathrm{Zr}-2$ (0.18 barn) [6], more thermal neutron contributed to neutronic calculations when $\mathrm{SiC}$ was used. As a result, when $0.75 \% \mathrm{NpO}_{2}$ fuel and $\mathrm{SiC}$ cladding material were used, neutron flux, fission energy and heating neutronic values were higher than other fuel and cladding materials.

\section{Competing interests}

The authors declare that they have no competing interests.

\section{Authors' contributions}

All authors have contributed to all parts of the article. All authors read and approved the final manuscript. 


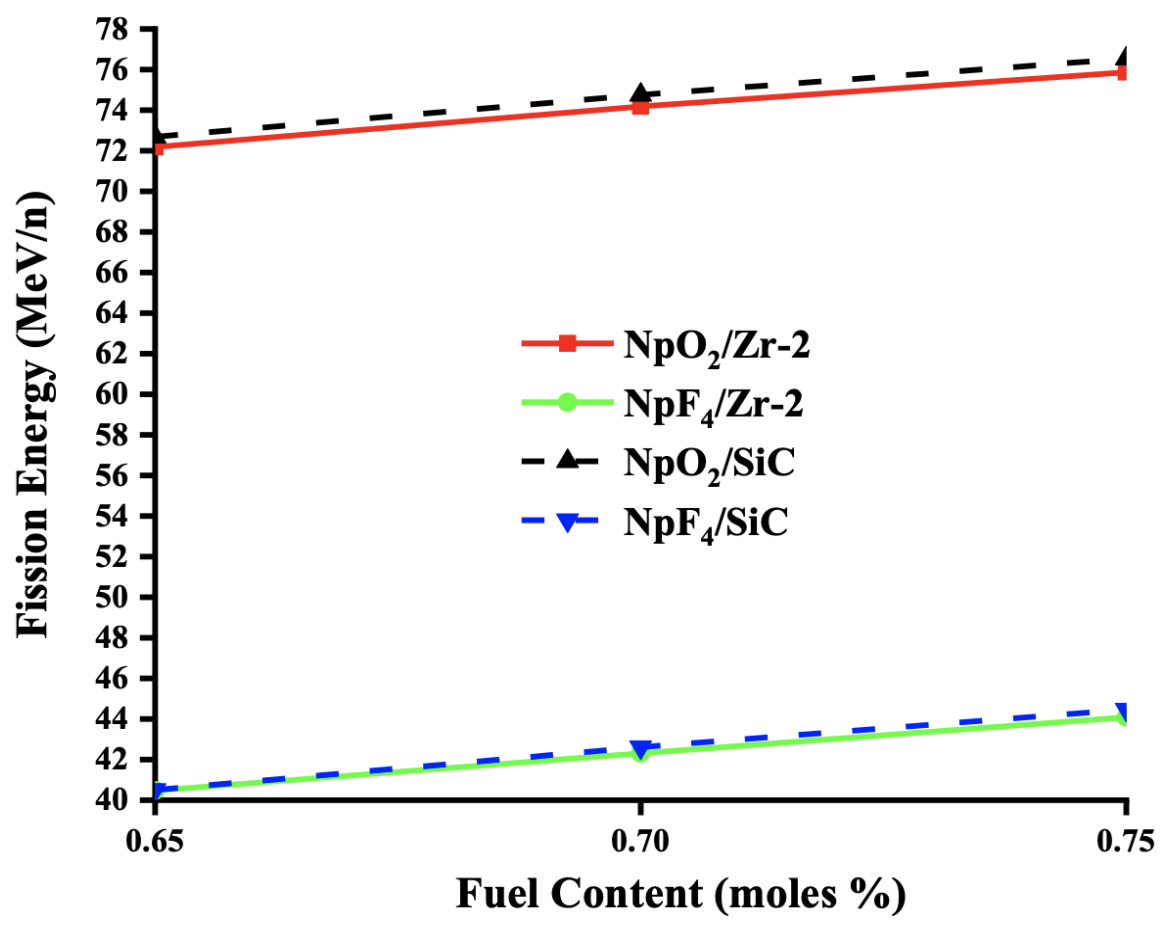

Fig. 4: The fission energy for $\mathrm{Zr}-2$ and $\mathrm{SiC}$ clads, the fuel components $\mathrm{NpO}_{2}$ and $\mathrm{NpF}_{4}$

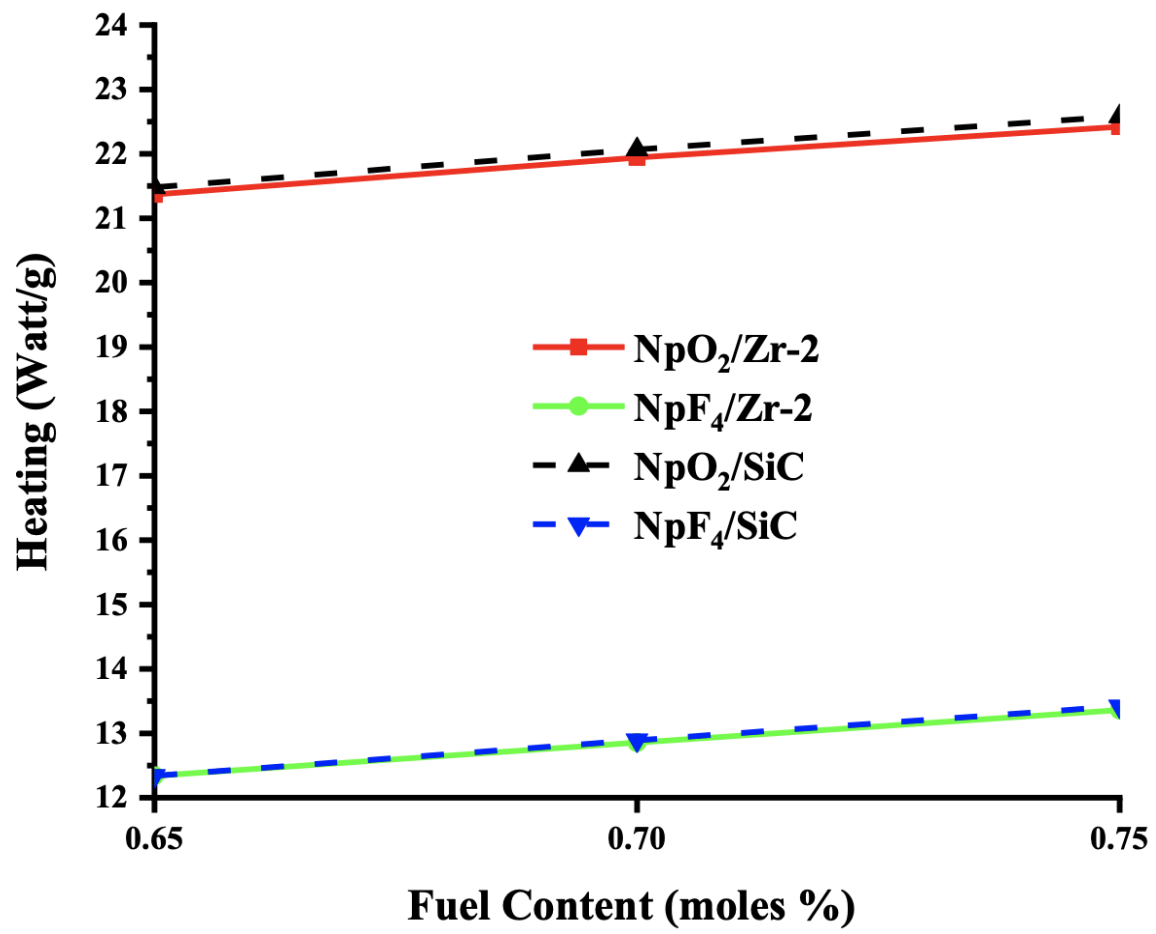

Fig. 5: The heating values for $\mathrm{Zr}-2$ and $\mathrm{SiC}$ clads, the fuel components $\mathrm{NpO}_{2}$ and $\mathrm{NpF}_{4}$ 


\section{References}

[1] Düz, M. (2021). Neutronic Calculations for The Certain Americium Mixed Fuels and Clads in a Boiling Water Reactor, Frontiers in Energy Research. doi: 10.3389/fenrg.2021.639416

[2] Şahin, S., Khan, M.J., Ahmed, R. (2011). Fissile fuel breeding and minor actinide transmutation in the life engine. Fusion Eng. Des. 86, 227-237. doi:10.1016/j.fusengdes.2011.01.002

[3] Düz, M. \& İnal, S. (2020). The effect of different fuels and clads on neutronic calculations in a boiling water reactor using the Monte Carlo method. Scientific Reports. doi: 10.1038/s41598-020-79236-8

[4] Waters, L.S. (ed.). MCNPX User's Manual,Version 2.3.0. LA-UR-02-2607 (2002).

[5] Prael, R.E., Lichtenstein, H. User Guide to LCS: The LAHET Code System, Los Alamos National Laboratory Report. LA-UR-893014 (1989).

[6] Zhou, B. \& Feng, K. (2018). Zr-Cu alloy filler metal for brazing SiC ceramic. RSC Adv. 8, $26251-26254$. doi:10.1039/C8RA05480K 